\title{
The Relationship between Chinese Law and Common Law in Malaysia, Singapore, and Hong Kong
}

\author{
M. B. HOOKER
}

$\mathrm{T}$ HERE is a considerable body of literature on the relationship between common law and various systems of personal laws especially in the Asian context. My only excuse for adding yet another account is this: A technical legal description of this relationship, focusing on such topics as marriage, divorce, inheritance, and so on, adds a real and important dimension to the study of culture contact. Except in Hong Kong, common law is no longer the dominant political system; it has become, with local variations, "government law" in the territories under consideration. Since law is the instrument most often used in the implementation of new government policies affecting family matters, for example, it seems important that some attempt be made to describe the techniques of interaction and to set out the present law as accurately as possible. Hopefully this essay will serve as skeleton reference material on the relation between these two systems of law. To accomplish this aim I will: (a) describe the ways in which the common law has been adapted so as to take account of Chinese law, (b) state the "principles of Chinese law" which the courts have formulated in the course of this adaptation, and (c) note the points at which the respective courts in the three territories have differed in their interpretation regarding the content of Chinese law.

The materials on which this paper is based are the relevant statutes and judicial decisions of the territories, plus, in the case of the former Straits Settlements, a report on Chinese marriages (1926) and, in the case of Hong Kong, a report on Chinese law and custom (r953). A cautionary note needs to be inserted here with respect to Singapore and Malaysia. These states, as now constituted, share a legacy of common law but the respective histories of this law are dissimilar. Singapore and the present states of Penang and Malacca in Malaysia were once part of the colony of the Straits Settlements. The states of Perak, Pahang, Selangor and Negri Sembilan were once part of the Federated Malay States. The remaining states of Malaysia were part of the Unfederated Malay States. The present federal states of East Malaysia, Sabah and Sarawak, were once the colony of North Borneo. The judicial histories of these areas vary and where the variation is relevant it is pointed out in the body of this paper.

\section{The Legal Bases of Chinese Law}

The Straits Settlements (Singapore, Penang and Malacca). These three settlements which came under the control first of the East India Company, later of the India Office, and finally of the Colonial Office were provided with a series of charters known as Charters of Justice. The Charters (dated 1807, 1826, and 1855) provided for

M. B. Hooker is LL.M. Barrister and Solicitor of the Supreme Court of New Zealand, and Lecturer in Law at the University of Singapore. 
the setting up of courts and a judicial service: they also provided that the law in each of the settlements was to be English law and was to apply to Europeans and to natives in "so far as the several religions, manners and customs of the inhabitants will admit." This interpretation of this phrase and the decisions as to how far English statute applied in the colony have resulted in a series of cases which are well-known and need no further comment here. ${ }^{1}$

In addition to the provisions in the Charters, Chinese law has received a basis for its application through the use of private international law principles. ${ }^{2}$ This is mainly illustrated in cases involving polygamous marriages, adoptions, and legitimations. In the case of marriage, the rule at common law has always been that marriage is monogamous. ${ }^{3}$ However, the courts in the Straits Settlements have decided that since it was lawful for a Chinese domiciled in China to take a secondary wife, at least before May, I931, ${ }^{4}$ then the Chinese as a whole are polygamous. ${ }^{5}$

In respect of a husband's rights over his wife's property, the common law gave certain specific rights. ${ }^{6}$ But the courts in the Straits Settlements held that a marriage contracted between Chinese according to Chinese rites conferred no marital rights on the husband with respect to his wife's property. ${ }^{7}$ So far as legitimacy was concerned this was determined by birth in lawful wedlock (common law) or by virtue of statute. But in the Straits Settlements the status of legitimacy was held to depend upon the law of China. Legitimation likewise depended upon the domicile of the father: in the case of a father possessing a Chinese domicile, legitimation by subsequent monogamous or polygamous marriage was possible. ${ }^{8}$ Somewhat inconsistently, the courts have rejected legitimation by subsequent recognition. ${ }^{9}$

The application of private international law principles in the Straits Settlements

\footnotetext{
1 Summarized in R. St. J. Braddell, The Law of the Straits Settlements: A Commentary 2 vols (2nd ed., Singapore, I93I). See vol. I, 62-94. Attention is directed especially to the following judicial decisions: $R$. v. Willans, 3 Ky. 16; Choa Choon Neoh v. Spottiswoode, 1 Ky. 216; Ong Cheng Neo v. Yeap Cheah Neo and ors. I Ky. 326. In the goods of Khoo Chow Sen, 2 Ky. Ecc. Rs. 22; Tan Kiong v. Ou Phaik (1900) 5 S.S.L.R. 77.

2 The earliest example of this basis is a statement by Maxwell C. J. in Chulas v. Kolson (1877) Leicester's Reports, 462 where the Chief Justice said: "their own laws or usages must be applied to them on the same principles and with the same limitations as foreign law is applied by our courts to foreigners and foreign transactions."

${ }^{3}$ Hyde v. Hyde, L.R. I, P. \& D. 130. The judge in this case, however, expressely limited the application of this principle to societies where polygamy is not recognized.

4 The Chinese Civil Code seems to have made some attempt to prohibit polygamy. cf. Book IV, Art., 985, “. . . a person who has a spouse may not marry again." The Code did not, however, place any restriction on the formalities required to celebrate a marriage except that there should be some ceremony, that the marriage should be open to the public, and that there be two or more witnesses. Art., 982 . cf. J. V. Mills, "Marriage in England, Singapore, and China," $3 \mathrm{I}$ Journal of Comparative Legislation and International Law Series 3, Part II, 25-36 at p. 28. On the problems which Art., 985 raised for many Chinese cf. H. McAleavy, "Some Aspects of Marriage and Divorce in Communist China" in J.N.D. Anderson (ed.) Family Law in Asia and Africa (London 1968) pp. 73-89 at pp. 73-74. In China Shiu Sui Ping v. Chan Din Tsang [1958] H.K.L.R. 283, the Hong Kong court recognized a Chinese customary marriage which took place in China after May I93I. This marriage was recognized for divorce purposes as being "a Christian marriage or its civil equivalent," Hong Kong Divorce Ordinance I952, s. 2.

"Khoo Hooi Leong v. Khoo Chong Yeok [1930] A.C. 346 at 352. Cheang Thye Pin v. Tan Ah Loy [1920] A.C. 369 . Khoo Hooi Leong v. Khoo Hean Kwee [1921] A.C. 529.

See C. H. Withers Payne. The Law of Administration of and Succession to Estates in the Straits Settlements (1932) 25 ff.

7 Lim Chooi Hoon v. Chok Yoon Guan (1893) I S.S.L.R. 72.

8 Re Choo Eng Choon (I9II) I2 S.S.L.R. I 20 at 224 ff.

' Khoo Hooi Leong v. Khoo Chong Yeok [1930] A.C. 346.
} 
was plagued by difficulties. By the very nature of the conflict, where one of the systems of law was unwritten or if written was subject to local modification, difficulties of proof were common. This difficulty was made greater by admitted local variations in Chinese law. Further, English conflict rules pre-supposed a relatively settled domicile and also the existence of a technical legal system not unduly affected by such matters as race or religion. Neither of these assumptions was fully justified in the Straits Settlements. This has led to some internal inconsistencies such as the recognition of legitimation by subsequent marriage but not by subsequent recognition. ${ }^{10}$

Finally the courts in the Straits Settlements have recognized Chinese law and custom on the ground of "natural justice." In the present context this appears to cover such matters as the interpretation of common law in dependent territories, the application or non-application of common law distinctions outside England, and the assumptions made by judges. ${ }^{11}$ In Penang and Malacca this position remains unchanged, but in Singapore Chinese law now has no effect because of the provisions of the Women's Charter (Ordinance I8 of 1961, amended by Ordinance 9 of 1967).

The Federated and Unfederated Malay States. Generally, the law applicable in any Malay State at the time when it became subject to British protection remained in force notwithstanding the treaty. It was subject only to legislative amendment. There was local legislation in the Federated Malay States but not in the Unfederated States. The legislation was piecemeal and left many gaps which the judges attempted to fill as well as they could. The outstanding example of this is the Selangor case of $R e$ Yap Kwan Seng's Will ${ }^{12}$ where the judge had to consider whether the rule against perpetuities applied in that state. In the course of the judgment it was said ${ }^{\mathbf{1 3}}$ that the general law of England was never adopted in this state though English principles and models were utilized. The judge recognized the rule against perpetuities on the grounds of public policy and of comity with the laws of the Straits Setrlements. ${ }^{14}$

Johore, an Unfederated Malay State, had adopted part of English law on the grounds of comity with the Federated States and the Straits Settlements. In addition the court found that an interpretation of the terms of Johore legislation demanded the use of common law principles. ${ }^{15}$

This brings us to the systems of legislation in the two classes of Malay States. In each of the Federated States there was legislation known variously as Orders in Council and Enactments. ${ }^{16}$ The state legislation was published in a revised edition in 1935 and showed the law in force as of 3 I December 1934 .

In the case of the Unfederated States, each of them was governed by the laws of their respective State Councils. The legislation from these States has been irregular,

\footnotetext{
10 For a summary of the whole topic of private international law principles in the Straits Settlements see J. V. Mills, "Marriage in England, Singapore, and China," $3 \mathrm{I}$ Journal of Comparative Legislation and International Law (1949) Series 3, Part 11, 25-36.

11 Examples of this can be found in Carolis de Silva v. Tin Kim (1904) 9 S.S.L.R. 8. Cheng Ee Mun v. Look Chun Heng [I962] M.L.J. cxxxvi (comment) and 4 II (report).

12 (1924) 4 F.M.S.L.R. 313.

13 (1924) 4 F.M.S.L.R. $316-18$.

14 The courts have also applied rules of equity in the Federated Malay States. Motor Emporium v. Arumugam [1933] M.L.J. 276 at 278 (Selangor).

15 Goh Eng Seong v. Tay Keng Seow [1935] M.L.J. 50.

${ }^{16}$ Negri Sembilan from 1883 , Pahang from 1889 , Perak and Selangor from 1877 .
} 
and only from Johore and Kedah are there revised editions of the laws. Authority on the hierarchy of precedent is sparse but in cases concerning Chinese law and custom the courts seem to have assumed a uniform body of Chinese custom and have given effect to Straits Settlements and Federated Malay States decisions. ${ }^{17}$

In only one of the states of Malaya, Perak, has there been any legislation in Chinese law. This is found in Perak Order in Council No. 23 of 1893 as amended by Order in Council No. 26 of 1895 . This purported to lay down the substance of Chinese law in the State of Perak as to marriage, adoption, inheritance, and intestacy. This order has been considered in three cases. In Yap Tham Thai alias Yap Fook Siong v. Low Hup Neo ${ }^{18}$ the court held that the estate of an intestate Chinese dying domiciled in Selangor should be distributed according to the principles set out in the Perak Order in Council as modified by local custom. In Teh Suan v. Ang Thuan and anor. ${ }^{19}$ the court approved the order as stating the Chinese law of infancy. In Tan Sim Neoh v. Soh Tien Hock ${ }^{20}$ the court approved the adoption of a son despite provisions of the order which provided to the contrary.

We can conclude that the legal basis of Chinese law in these states has been largely an ad hoc recognition by the courts with only minor legislative assistance. This is in strong contrast to the position in the Straits Settlements. Chinese law remains a valid system of personal law in these states today and it is almost completely case law.

Sabah, Sarawak and Brunei. The position in these states presents some contrast to legal bases in both the Straits Settlements and in the Malay States. In Kho Leng Guan v. Kho Eng Guan ${ }^{21}$ the court stated the sources of law in Sarawak as:

(a) Orders or written laws enacted by or with the authority of the Raja.

(b) English law in so far as it is not modified by (a) and in so far as it is applicable to Sarawak.

(c) Certain law and custom of races indigenous to Sarawak including the Chinese. The court also said that whether or not Chinese law is to be admitted is a question which must be determined according to the rules of English law.

These general principles have been defined, expressly in respect of Chinese, in Chan Bee Neo and ors. v. Ee Siok Choo.22 The court held that it would apply Chinese custom:

(a) When the custom is expressly regulated by a Sarawak Ordinance; or

(b) When the custom is expressly regulated by rules made under an Ordinance; or

\footnotetext{
17 See the cases eited in the most recent decision on Chinese custom. In Re Ding Do Ca decd. [1966] M.L.J. 6. It was held, however, that the courts of the Federated Malay States had no jurisdietion to deal with issues affecting conjugal rights among the Chinese. Choi Wai Ying v. Cheong Weng Chan and ors. [1933] M.L.J. 301. See also Lim Chye Peow v. Wee Boon Tek (187I) I Ky. 236, but see contra $R$. v. Loon: re Khu Lak Neoh (1864) W.O.C. 39 .

${ }^{18}$ (1922) I F.M.S.L.R. 383; (1925) 6 F.M.S.L.R. I3.

10 (Ig22) 2 F.M.S.L.R. 43.

20 (I922) I F.M.S.L.R. 336.

21 [I928-4I] S.C.R. 6o.

22 [1947] S.C.R. I.
} 
(c) Where the custom is recognized expressly or impliedly in a Sarawak Ordinance. ${ }^{23}$

The actual effect of these two decisions is illustrated in Li Khoi Chin v. Su Ah Poh ${ }^{24}$ where it was held that the validity of a Chinese marriage in Sarawak is dependent upon registration. In a later case, Chiew Boon Tong v. Goh Ah Pei and anor., ${ }^{25}$ the court in Sarawak held that a marriage is not valid unless registered under the provisions of the Chinese Marriage Ordinance (cap. 74).

This brings us to a situation where there is direct legislative authority in the provisions of Chinese law. This is also the situation in Brunei. ${ }^{26}$ So far as Chinese law is concerned there are, however, two reported cases which show elements of conflict. In Liu Kui Tze v. Lee Shak Lian ${ }^{27}$ the High Court of Sarawak, North Borneo (as it then was), and Brunei had jurisdiction in divorce with respect to Chinese customary marriages on the following grounds:

(a) That the present court is the direct successor to the "Chinese Court" first set up by Order IX of igrr.

(b) That this jurisdiction has not been disturbed by any later order or enactment.

(c) That the practice of the former Resident's Courts has always been to take jurisdiction in respect of these marriages.

However, in Lim Siew Yun v. Soong Ah Kaw ${ }^{28}$ the court in Brunei held that it had no jurisdiction on Chinese divorce on the ground that there was no legislation conferring such jurisdiction. The present position in these states thus remains somewhat obscure.

Hong Kong. The legal basis of Chinese law and custom in Hong Kong is set out in the Committee's Report ${ }^{29}$ on pages $4-5$ and pages $82-\mathrm{I} 2 \mathrm{r}$. This can be summarized in the following propositions. First, that in view of the Supreme Court Ordinances (beginning with No. 15 of 1844 and ending with the Ordinance of 1873 ) the effect was to introduce English law as it was in 1843 as the general law of the Colony. The main question for determination is the construction of section 5 of the Ordinance of 1873 which provides that English law shall be the law of the colony except insofar as it is inapplicable to local circumstances or to the customs of its inhabitants or is modified by local legislation. ${ }^{30}$ In Appendix I, (pp. 82-121) which is concerned with this question, the Committee considered Straits Settlements cases in opposition to Hong Kong cases. The Committee concluded (though not unanimously) that English law was the general law of the Colony.

The committee recommended, however, that it should not be applied if it would

\footnotetext{
28 This was followed and applied in Wong Teck Giak and anor. v. Ting Ni Moi [1950] S.C.R. I and 39 (appeal).

24 [1950] S.C.R. I7.

25 [1956] S.C.R. 58.

28 This state is not part of the Federation of Malaysia but has a special relationship to it.

27 [ 1953] S.C.R. 85.

28 [ 1960-63] S.C.R. I05.

29 Chinese Law and Custom in Hong Kong. Report of a Committee appointed by the Governor in October I948. (Hong Kong: Government Printer, February, 1953.)

30 This is very similar to the provisions of the Straits Settlements Charters.
} 
cause injustice or oppression (pp. II4-15) or if Chinese law prima facie applied (pp. I15-17). On the other hand Chinese law should not apply if it would lead to the application of some doctrine fundamentally opposed to the conceptions of English law (pp. II7-19). The committee recognized that both laws should be modified by local legislation and cited the judgments in Ho Tsz Tsun v. Ho Au Shi \& ors. ${ }^{31}$ and Chan Shun Cho v. Chak Hok Ping ${ }^{32}$ as examples of this.

The various territories considered so far show some similarities and some differences in the attitudes of the courts to Chinese Law. The rest of this paper will be given over to description of the peculiar problems faced in each territory and problems common to all; and specifically the ways in which the courts have dealt with Chinese law and custom especially where they vary in their solutions.

\section{The Extent and Scope of Chinese Custom}

Before commencing with the substance of this section we should note the variable content of Chinese custom. The judicial decisions reported show that the courts, while using the words "Chinese custom" as a general term, have in fact been adjudicating upon somewhat localized rules as to marriage, divorce, adoption, etc. Indeed, this point emerges clearly if one compares, for example, the various Orders in Council (Perak Orders 23/1893 and 26/1895) and Reports on Chinese custom (Straits Settlements 1926 and Hong Kong 1953). This, of course, must seem perfectly obvious but the courts have sometimes been misled into regarding "expert evidence" or that body of laws known as the Ta Tsing $L u L i$ as stating a body of regulation common to all Chinese. ${ }^{33}$ Bearing this caution in mind we may consider the specific fields in which Chinese law and the common law have interacted.

The Money-Loan Association "Hwei."34 A hwei is a group of individuals who join together for the purpose of contributing money to a common pool over a fixed period of time. The contributions are made at meetings at which bidding for the contributions paid at that meeting takes place. The person who offers the highest rate of interest is the successful bidder. A simple example will illustrate this. Suppose a hwei is composed of ten persons who meet once a month and whose monthly subscription is $\$ 100.00$. In the first month the "head" collects $\$ 900.00$ and he keeps this sum as a loan to himself free of interest. In the second month the successful bidder will receive eight subscriptions plus the head's $\$ 100.00$ repayment and so on down until all have placed a bid. ${ }^{35}$

31 (1915) Io H.K.L.R. 69.

32 (1925) 20 H.K.L.R. I.

33 See for example: Nonia Cheah Yew v. Othmansaw Merican and anor. (186r) I Ky. 160; R. v. Sim Boon Lip (1902-03) 7 S.S.L.R. 4; Wong Pun Ying v. Wong Tin Hong [1963] H.K.L.R. 37. The Straits Settlements Chinese Marriage Committee (Singapore Government Printer, 1926), howcver, took evidence from the Straits and Chinese born Hokkien, Cantonese, Teochew, Hakka and Hailam communities.

${ }^{34}$ The spelling of this term (and sim-boo-kian on p. 732 below) is that used in the law reports and is continued here for ease of recognition when dealing with legal documents. Sometimes $H w e i$ is also referred to, incorrectly, as tontine.

${ }^{35}$ There is a Tamil version of this in Malaysia known as kuthu: see C. Gamba, "Poverty and some Socio-Economic Effects of Hoarding, Saving and Borrowing in Malaya." 3 Malayan Economic Review (1958) $33-56$ at $39-4$ I. 
The question which has confronted the courts in all the territories above is, what is the nature of the legal relationships which arise when a member defaults on payment of principal or interest? The courts have been unanimous in holding that a hwei is not a gambling association, neither is it a money-lending association. But they have been far from unanimous in deciding whether or not the members are related in law, and if they are related, then what the nature of this relationship is. A typical example of the confusion which has arisen is found in Fan Ngoi Lam and ors. v. Asia Cafe and anor. ${ }^{36}$ Here the court found that hwei consisted of a verbal agreement to be bound by the rules of the association, but the rules did not constitute an agreement or set of agreements between the head and each member. Later in the judgment the court said that "the nature [of the association] is one of mutual trust." And a little later the judge managed to say that it is "a mutual contract." There are two choices here: either it is an association based on some principle of equity or it is a contractual entity at common law. There is support for both choices.

Equity: The only support for this proposition, apart from Fan's case above, is to be found in two Hong Kong decisions. In Chan Ka Lam and ors. v. Cheung Chung Kong and anor, ${ }^{37}$ the court held that the head is a trustee in respect of monies paid to him by the members. In Un Yan Sing and ors. v. Fong Lun San ${ }^{38}$ the court said that the head was an implied trustee for the members and the court expressly founded its jurisdiction in equity and not in common law.

Common Law: There is greater support for the basis of the hwei being founded in contract but the nature of the contract and the extent of contractual relations is still a matter of dispute. The cases are divided between two alternatives. First, it has been held in seven cases that the contract is between the head and each member separately. From this it follows that the head is liable to each member for payment of subscription and for the repayment of loans. The receipt given by the member who obtains a loan is in the nature of a promissory note and, on proof of default, a member may sue the head for this sum. ${ }^{30}$

The second alternative is that each member contracts with all other members. The contract is to abide by the rules of the association and to observe all the liabilities necessary for its operation. ${ }^{40}$ The case of Loi Teck Uh v. Chieng Lee Tieh ${ }^{41}$ provides an interesting link between the two contractual situations. The court held:

(a) That the head contracts with each and every member to pay back each member's contribution and to guarantee repayment by each successful tenderer.

36 (1929-30) 24 H.K.L.R. I.

37 (I915) 10 H.K.L.R. I57.

38 (rgr3) 8 H.K.L.R. 89.

39 Chow Cham v. Yuet Seem (1910) 5 H.K.L.R. 233; Soo Hood Beng v. Khoo Chye Neo (1896) 4 S.S.L.R. II5 (manager is agent for members); Lau Chuo Kiew v. Hii Chee Soon [1966] M.L.J. 126; Lee Pee Eng v. Ho Sin Leow [1958] S.C.R. I 8 (an agreement to repay money tendered for and received is an enforceable agreement); Luk Dai Chung v. Ngu Ee Nguok [1966] M.L.J. I I9 (head may be liable to the members for the debt of a member); Ngu Ee Nguok v. Lee Ai Choon [1965] M.L.J. 32 (default by a member must be proved and the onus of proof is upon the person asserting); Tan Siew Hee $\mathcal{E}$ ors. v. Hii Sii Ung [1964] M.L.J. 385 (the receipt given by a successful tenderer, which is in the nature of a promissory note, raises the presumption of [oral] contract for which there must be consideration and evidence is admissible to show want of consideration).

10 Chan Iu Sang v. Tam Wai Sang (1927) 22 H.K.L.R. I29.

41 [1960-63] S.C.R. 325 . 
(b) The members contract with the head to lend money and to take part in the hwei.

(c) The members contract with each other through the head who is agent to tender and to make such payments as may be required.

The I.O.U. which is signed is a written acknowledgement of debt, though it is only prima facie proof of this and may be rebutted by other evidence.

The basis of hwei seems, then, to be founded in contract and not in equity since the members contract at least with the head to observe certain rules and conditions. ${ }^{42}$

Polygamous Marriages-Validity and Form..$^{43}$ Chinese polygamous marriages are valid in (east and west) Malaysia and in Hong Kong though no longer in Singapore. ${ }^{44}$ In West Malaysia and Singapore (prior to 196r or Ig67) recognition of these marriages demanded the satisfaction of three tests: (a) long continued cohabitation; (b) intention to form a permanent union, and (c) repute of marriage. These requirements, however, have not always been demanded and the Federated Malay States and Straits Settlements cases show variations in the courts's approaches to polygamy.

A summary of the relevant cases illustrates this. In Cheang Thye Phin v. Tan $A h L y^{45}$ the court held that it would presume a secondary marriage from evidence of cohabitation and repute. It also said that a ceremony was not essential for such a marriage. In Chu Geok Keow v. Chong Meng Sze $e^{46}$ the court said that mutual consent was necessary and that ceremony, contract, and repute are evidentiary only. In Re Khoo Thean Tek's Settlements ${ }^{47}$ the court said the element of "permanence" is necessary to constitute a valid secondary marriage and that factum and intention must be present upon which long habit and repute may be founded.

The courts have also, in some cases, stated that a presumption as to marriage exists in respect of secondary wives. In Ong Cheng Neo v. Yeap Cheah Neo ${ }^{48}$ the court laid the onus of proof on the person disputing the existence of a marriage. In Woon Kai Chiang v. Yeo Pak Yee $e^{49}$ the court held that where a Chinese male cohabits with a woman and subsequently marries (i.e. goes through a form of mar-

\footnotetext{
42 See also the statement of Lord Herschell in Clarke v. Dunraven [1897] A.C. 59 at 63 ... "undertaking to be bound by ... rules to the knowledge of each, is sufficient, I think, where these rules indicate a liability on the part of one to the other, to create a contractual obligation to discharge that liability. That being so, the parties must be taken to have contracted that a breach of any of these rules would render the party guilty of that breach liable. . .."

43 Such marriages cannot be contracted in Singapore possibly since 1961 but certainly from 1967Women's Charter (Ordinance 18 of 1961 as amended by 9 of 1967). However, the problem of polygamy linked with considerations of domicile may still give rise to proilems in Singapore Courts.

44 I agree with David Buxbaum (25 Journal of Asian Studies (1965-66), p. 639, footnote 78) that secondary relationships do probably continue in Singapore despite the Women's Charter.

45 (1921) 14 S.S.L.R. 79.

40 [196r] M.L.J. Io.

47 [1928] S.S.L.R. 178; [1929] S.S.L.R. 50 (appeal). See also: Lee Choon Guan decd.; Lew Ah Lui v. Choa Eng Wan [1935] M.L.J. 78; Lee Seang Neo and ors. v. Low Hin Tuan and ors. (1925) 5 F.M.S.L.R. 154; In the Estate of Lee Siew Kow decd. [1952] M.L.J. 184; Ngai Lau Shia v. Low Chee Neo (1921) 14 S.S.L.R. 35; Seow Beng Hay v. Seow Soon Quee [1933] M.L.J. III (a man may marry a $t$ 'sip-secondary wife-before a $t$ 'sai-first wife). Soh Eddie v. Tjhin Feong Fah [195I] M.L.J. r24; Tan As Bee v. Foo Koon Thye and anor. [1947] M.L.J. I69; Re Yeo Seng Whatt decd. [1949] M.L.J. 60 and 24I; Re Yeow Kian Kee decd. Er Gek Cheng v. Ho Ying Seng [1949] M.L.J. 17 I.

48 (1877) Leicester's Reports 3 I $4 .^{4}$

49 [1926] S.S.L.R. 27.
} 
riage) another woman, a presumption in favor of a former marriage arises. This may give rise to a further presumption that the woman is at least a secondary wife.

In Nonia Cheah Yew v. Othmansaw Merican and anor., ${ }^{50}$ the court held the material factors in proving a Chinese marriage were that the woman should be given away by her nearest male relative and that there should be some publicity among friends of the couple. This emphasis upon form does not appear so much in later cases. However, a Chinese marriage ceremony has been held to confer the status of (at least secondary) wife for purposes of statutory interpretation. ${ }^{51}$

The courts have distinguished between a valid polygamous marriage and bigamy and the principle was early laid down that the distinction must depend upon the relevant provisions of Chinese law. ${ }^{52}$

In Sabah and Sarawak the position on Chinese marriages is slightly different in that these marriages are regulated by statute ${ }^{53}$ and their validity is therefore to be judged by the requirements of the ordinance the most important of which is registration with a Registrar of Chinese marriages. ${ }^{54}$ In the case of an unregistered Chinese marriage only the court can determine whether it is valid. ${ }^{55}$

In Hong Kong the position of the law in respect of secondary marriages seems broadly similar to that in Malaya and Singapore. Thus, in $\mathrm{Ng}$ Ying Ho and anor. v. Tam Suen $Y u^{56}$ the evidence required to show that a woman was a $t^{t}$ sip included being received into the husband's family, and formally introduced to them, worshipping at the ancestral tablets, and serving tea to the principal wife.

The courts in each of the three territories mentioned above have had to face their own peculiar problems in respect of Chinese marriages. In Singapore, Malaysia, and Hong Kong, apart from the general question of polygamy, the problem of inter-racial marriages has arisen. There is only one reported case from Hong Kong, In Re the Estate of Kishan Das. ${ }^{57}$ The court was asked to decide upon the validity of a marriage between a Hindu man and a Chinese woman celebrated according to Hindu rites. It was held that since there was no evidence of the woman having become a Hindu, the marriage was invalid. The court specifically said that the lack of such evidence rebuts the presumption of marriage. In this decision there seems to have been an undue reliance upon the form of marriage which also tends to determine capacity.

In the Straits Settlements and Malay States cases this has been avoided. In Carolis de Silva v. Tin $\mathrm{Kim}^{58}{ }^{58}$ the court determined the validity of a marriage between a Singalese man and a Chinese widow on the grounds of cohabitation and repute. Perfection of form was held not to be essential to validity. Similarly in In re Tay Geok Teat decd. ${ }^{59}$ the court determined the validity of a marriage between a Chinese man and a Japanese woman on grounds of cohabitation and repute.

However, the recognition of inter-racial marriage has not been without difficul-

50 ( 1877 ) Leicester's Reports 167.

51 Soong Voon Sen v. Ang Kiong Hee [1933] M.L.J. 262.

32 R. v. Yeah Boon Leng (1890) 4 Ky. 630: see also R. v. Sim Boon Lip (1864) W.O.C. 39 and R. v.

Teo Kim Choon [1947] S.L.R. $5^{8}$.

${ }^{53}$ The Chinese Marriage Ordinance, 1933 (Cap. 74 revised laws r946-see especially section 4).

54 Chien Boon Tong v. Goh Ah Pei and anor. [1956] S.C.R. 58.

55 Chien Boon Tong v. Goh $A h$ Pei and anor. [1956] S.C.R. 58.

66 [1963] H.K.L.R. 923: see also Au Hung Fat v. Lam Lai Ha [1959] H.K.L.R. 527.

57 (1932-33) 26 H.K.L.R. 42.

58 (1904) 9 S.S.L.R. 8.

59 [1934] M.L.J. 83 . 
ties: these have resolved around the notion of consensus ${ }^{60}$ as being the fundamental element of common law marriages. The outstanding example of this situation is the decision in Re Abraham Penhas decd ${ }^{61}$ The case decided the validity of a marriage between a Jewish man and a Chinese woman celebrated in Singapore by Jewish and Chinese rites on the basis that it was a common law marriage. The Privy Council held that as there was consensus to enter into a marriage, the marriage was valid. Consensus was taken as a sole criterion but in respect of marriages between two Chinese the courts have found that the elements of intent, cohabitation, and repute are necessary to establish validity.

There are thus two sets of requirements: where one party only is Chinese then the common law marriage doctrine of consensus applies. An essential element to this is that the marriage is monogamous. On earlier authority, if both parties are Chinese then three requirements are necessary.

However, in Yeow Kian Kee decd: Er Gek Cheng v. Ho Ying Seng ${ }^{62}$ a Chinese secondary marriage was found to exist solely on the basis of consensus. How is this to be reconciled with Penhas? If Penhas is accepted then the doctrine of consensus should apply to Chinese secondary marriages. But this is not possible. On the other hand, if Penhas is rejected then it is not possible to have a valid common law marriage except where one of the parties is racially non-Chinese. This is quite unacceptable.

These two decisions should be read in the light of Yee Yeng Nam v. Lee Fah Kooi. ${ }^{63}$ This decision makes clear that in Malaysia it is possible for Chinese to contract marriages which may be either monogamous or polygamous at inception. It seems from the tenor of the decision that the type of marriage actually existing between the parties is a matter of fact to be proved to the Court's satisfaction. In this case the marriage was held to be monogamous because the parties were married under the Straits Settlements Christian Marriage Ordinance 1940, which, though it does not provide that a marriage under its provisions is monogamous, enables persons married under it to enter into a monogamous marriage.

The courts in the former North Borneo Territories have not had to face this problem but have had their own particular problem. This has resolved around the custom known as sim-boo-kian. This describes the situation where a girl is "purchased" for a sum of money with the intention of bringing her up as a prospective bride for the son of the family. The purchase price is known as brian ${ }^{64} \mathrm{~A}$ breach of the agreement by taking the girl away, for example, is liable to result in the payment of damages and/or the return of brian. This form of marriage was recognized in Yek Hing Po v. Tou Nih Hiong ${ }^{65}$ but in Pang Chin v. Pang Chon

${ }^{60}$ On consensus generally see $R$. v. Willis $(1843-44)$ Cl. \& F. 534 .

61 [1950] M.L.J. I04; [1953] A.C. 304 cf. Maurice Freedman, "The Penhas Case: Mixed and Unmixed Marriage in Singapore," 16 Modern Law Review, (1953) 366-68.

62 [1949] M.L.J. I71.

63 [1956] M.L.J. 257.

64 This term is not Chinese and it does not appear in any of the standard Malay or Indonesian dictionaries. It appears to be Dyak and is used to mean bride price: see 4 Sarawak Museum Journal (I935) No. I5, Part IV, 395 .

${ }^{65}$ [1953] S.C.R. 59: see also Chia Ah Kiaw v. Tan Ka Yong [1928-4I] S.C.R. II5. 
$P e e^{86}$ the court refused to recognize the custom of "buying and selling children" on the somewhat humorous ground that this was not a valid contract of sale at common law. The court has, however, upheld a marriage where a girl was given to a family so that she might become the wife of a son of the family. ${ }^{67}$

Divorce. This question has provided little difficulty in any of the three territories. There is only one reported case from Hong Kong and from the views of the committee $^{68}$ divorce appears to be laid down in the $C h^{\prime}$ ing law. The outstanding feature of this law is that it provides for divorce by mutual consent. In Lee Wah Fui v. $\operatorname{Lan}^{69}$ the court held that a contract of mutual divorce was sufficient to dissolve a marriage celebrated in Hong Kong according to customary rites.

In Malaya and (prior to 1961) in Singapore the law regarding Chinese customary divorce is well settled. A secondary wife may be divorced if she has shown disobedience to her husband or to the principal wife; if she has been guilty of immoral conduct. In addition, a husband must notify his relatives and clansmen of the divorce. ${ }^{70}$ On the general principle of divorce the courts have held that Chinese may only divorce according to custom so long as they marry under custom. If they marry under the provisions of any ordinance, then the grounds of divorce must be as determined by the ordinance. ${ }^{71}$ The courts will not allow a woman to divorce her husband unilaterally. ${ }^{72}$

Customary divorce in former North Borneo is recognized by the courts on the general principle that the court has jurisdiction because the present High Court is the direct successor to the "Chinese Court" (Order IX, I9II), that this jurisdiction has not been disturbed by any later order or enactment and because the practice has always been to grant divorces in respect of Chinese marriages. ${ }^{73}$ The jurisdiction has been extended to cover decrees of judicial separation. ${ }^{74}$ The courts have insisted that the practice of mutual divorce, which they recognize, has no effect without a declaration by the court. ${ }^{75}$

Unlike the courts in Malaya and the former Straits Settlements the courts in Sarawak, Sabah, and Brunei have not laid down general principles on grounds for divorce. They have instead preferred to accept evidence on a case by case basis as to the custom of different dialect groups. In one case the court even accepted, on the basis of expert evidence, that there was no custom governing Hakka divorce as the practice was to leave this matter to the courts. ${ }^{76}$ This is probably incorrect, the weight of authority being against such a conclusion.

60 [1952] S.C.R. 18.

${ }^{67}$ Loh Chai Ing v. Lau Ing Ai [1959] S.C.R. 13. This was a Foochow marriage and is known as a T'ung Yang-Hsi marriage. cf. sim-boo-kan above.

${ }^{88}$ Chinese Law and Custom in Hong Kong-report of a committee, (Government Printer 1953). See pp. $26-28,46-49$.

${ }^{69}[1964] 2$ All. E.R. 248: Buxbaum, 25 Journal of Asian Studies (1965-66) 641 note 86.

70 Re Lee Gee Chong decd. [1965] M.L.J. 102. In the estate of Sim Siew Guan decd. [1932] M.L.J. 95: see also Woon Ngee Yew \& ors. v. Ng Yoon Thai \& ors. [194I] M.L.J. 32.

71. Re Soo Hai San and Wong Sue Foong [196r] M.L.J. 221.

${ }^{2}$ Cheng Ee Mun v. Look Chun Heng and anor. [1962] M.L.J. $41 \mathrm{I}$.

${ }^{73}$ Liu Kui Tze v. Lee Shak Lion [1953] S.C.R. 85.

${ }^{74}$ Chien Mau Ong v. Wong Suok [1956] S.C.R. 97: compare Lim Siew Yun v. Soong Ah Kaw [1960-63] S.C.R. 105.

${ }^{73}$ Wong Chu Ming v. Kho Lieng Hiong [1952] S.C.R. I.

76 Yong Mong Yung v. Chai Shong [1964] M.L.J. 424. 
The courts have accepted the following grounds for divorce:

Foochow:

(a) desertion; ${ }^{77}$

(b) failure to maintain ${ }^{78}$

(c) that the parties are completely out of sympathy and find it impossible to live together. ${ }^{79}$ The court refused to recognize lack of intelligence as a ground for divorce. ${ }^{80}$

Hakka:

(a) if both parties agree to a mutual divorce; ${ }^{81}$

(b) failure to maintain; ${ }^{82}$

(c) if the wife has left and there is no possibility of reconciliation. ${ }^{83}$ In an earlier case the court refused to recognize this ground. ${ }^{84}$

Henghua: ${ }^{85}$

(a) ill treatment by the husband;

(b) failure to maintain for at least a year.

Adoption and the Rights of Adopted Children to Succeed to Property. The Hong Kong courts have consistently recognized adoption on the basis of $T^{\mathrm{V}}$ sing law. ${ }^{86}$ The primary reason for adoption has been held to be to prevent the extinction of a family and an adoption for such a purpose is valid. ${ }^{87}$ As proof of an adoption the court has accepted as evidence that formalities of adoption have been performed and that records of the adoption exist in the form of records in family books, at temples and inscribed on tablets. ${ }^{88}$ The custom of adoption will be given effect to so long as it does not conflict directly with any ordinance. The Infants' Custody Ordinance (cap. 13), for example, has been held not to be inconsistent with customary adoptions in Hong Kong. ${ }^{89}$

So far as Hong Kong is concerned, the committee appears to have assumed that an adopted child stands in all respects as a legitimate natural born child in the matter of succession. This has not been the case in Malaya and Singapore regarding either testate or intestate property. Most of the reported cases have re-

${ }^{77}$ Lee Yung Kiang v. Ling Yun Tie [1965] M.L.J. 87. See also Tang Sui Ing v. Goh Tien Liong [1964] M.L.J. 406.

${ }^{78}$ Loh Chai Ing v. Lau Ing Ai [1959] S.C.R. 13. See also Tang Sui Ing v. Goh Tien Liong [1964] M.L.J. 406 .

${ }^{28}$ Tang Sui Ing v. Goh Tien Liong [1964] M.L.J. 406.

${ }^{80}$ Loh Chai Ing. v. Lau Ing Ai [1959] S.C.R. 13.

${ }^{81}$ Kong Nyat Moi v. Leong Sing Chiang [1965] M.L.J. 73.

82 Lo Siesu Ying v. Chong Fay [1959] S.C.R. T.

${ }^{83}$ Lo Siew Ying v. Chong Fay [1959] S.C.R. I.

84 Thia Whee Kiang v. Kueh Eng Seng [1955] S.C.R. 75.

85 Siaw Moi lea v. Lu Ing Hui [1959] S.C.R. I6.

${ }^{86}$ Chinese Law and Custom in Hong Kong-report pp. 49-53. The committee cited an extract from a report made in 1883 which contained "forms" for the transfer of a son and deed of sale of a son into adoption and a letter of instructions referring to an adopted son, see pp. 194-99. See also In the goods of Chan Tse Shi (1954) $3^{8}$ H.K.L.R. 9; Wong $Y_{u}$ Shi and ors. v. Wong Yin Kuen [1957]

H.K.L.R. 420; Chan Yue (alias) v. Henry G. Leong Estates Ltd. (1953) 37 H.K.L.R. 66.

87 In the state of Ngai I: Ngai Chung Shi and anor. v. Ngai Yee Mui (I927) 22 H.K.L.R. Io5.

${ }^{88}$ Cheang Thye Gan v. Lim Ah Chen and ors. (1921) I6 H.K.L.R. 19.

${ }^{89}$ Lui Yuk Ping v. Chow To [1962] H.K.L.R. 515. 
quired the court to make a decision as to whether the term "children" in a will means adopted children. The weight of authority is to the effect that it does if this can be gathered from the terms of the will itself. ${ }^{90}$

So far as intestate property is concerned, the position is less clear. In $\mathrm{Re} C h u$ Siang Long $^{91}$ the court held that the adopted child of a Chinese was entitled to the joint administration of an estate in preference to a nephew. This decision was expressly based on the provision of the charters which directed that respect be given to local custom. However, this decision was overruled in Khoo Tiang Bee et Uxor v. Tang Beng Gwat ${ }^{92}$ on the grounds that the law as to Chinese adoptions is uncertain, and that it would add one more to the many conflicts of laws in the Straits Settlements where the uniformity of the laws of inheritance must be preserved as far as possible. Some support for the first ground is given in In the goods of Goh Siew Swee decd. ${ }^{93}$ where the court refused to accept books on Chinese law as evidence.

It is probably settled law now that adopted children will not succeed to an intestate estate in Malaya. This is because the Distribution Ordinance 1958 restricts the status of adoption to persons formally adopted under the Adoption Ordinance of $1952 .{ }^{84} \mathrm{~A}$ similar situation exists in Singapore under the provisions of the Women's Charter.

In Sarawak, Sabah, and Brunei there is no direct authority on adoption, but it is likely that the courts will demand that to. be valid it must be regulated or recoginzed (expressly or implicitly) by some ordinance. Thus in Wong Teck Giak and anor. v. Ting $\mathrm{Ni} \mathrm{Moi}^{95}$ the court decided the question of custody of a child on these criteria. In $L i$ Khoi Chin (aliases) v. $S u A h P o h^{96}$ the court said that the law of Sarawak would recognize an adoption made outside Sarawak where the persons concerned were domiciled in the country of adoption.

Legitimacy and Legitimation. This topic is almost entirely confined to Malaya. There are no Hong Kong decisions reported, and the topic is not now relevant in Singapore. There is, however, one case from Sarawak ${ }^{27}$ on intestate succession and legitimation by subsequent recognition. The court held that this form of legitimation would be recognized on the basis of Chinese custom. ${ }^{98}$ The courts in the Straits

\footnotetext{
90 Cases to the effect that "children" means adopted children: In re Kho Khye Chear decd. [1938] M.L.J. 224; In re Lim Yew Teok decd. [1937] S.S.L.R. 243; Quaik Kee Hock v. Wee Geok Neo [1886] 4 Ky. 128; Re Tan Hong decd. [1962] M.L.J. 355; Re Teo Soo Piah decd. [1950] M.L.J. 176; Re Yeo Soo Theam decd. 1937 S.S.L.R. 276; Cheok Chin Huat v. Cheok Chin Soon [1937] S.S.L.R. 103; Re Tan Cheng Siong decd. [1937] S.S.L.R. 293; Tan Phee Teck v. Tan Tiang Hee [1952] M.L.J. 240.

91 ( 1877 ) Leicester's Reports 460.

92 (1877) I Ky. 413. This case was cited with approval by the Privy Council in Re Choo Eng Choon decd. [1930] A.C. 346 at 355 .

83 (I9II) I2 S.S.L.R. I 8.

94 See Re Loh Toh Met: Kong Lai Fong v. Loh Heng Peng [1961] M.L.J. 234. Similarly, the adoption of a person into the family of a man already deceased at the time of adoption is no longer validsee Tan Sim Neoh v. Soh Tien Hock (1922) I F.M.S.L.R. 336.

95 [I950] S.C.R. I and 39 (appeal).

${ }^{80}$ [1950] S.C.R. I7.

97 In the estate of Chan Chin Hee decd. [1948] S.C.R. 6.

98 The court approved the following grounds: (a) If the parents of the father wish to recognize the child. (b) If other elders of the family wish to recognize the child provided the father consents. (c) A person's name carved on a tombstone is evidence, not necessarily conclusive, of his legitimation.
} 
Settlements and Federated Malay States have consistently refused to give effect to this form of legitimation. ${ }^{99}$

However, legitimation by subsequent marriage was and (in Malaya) is recognized. ${ }^{100}$ The reason for this is that this is an issue which must be decided with regard to the validity of the union between the parents and the obligations arising out of that union as set out by Chinese law and custom.

It is difficult to see why this principle should not be extended to legitimation by recognition. The position on this subject may very well vary as between the states of West Malaysia and East Malaysia and this is unfortunate.

The topic of wills falls into two main categories: (a) construction; and (b) trusts for charitable uses and the rule against perpetuities.

Construction: There is very little material from Hong Kong on the topic of wills generally. The matter was formerly governed by the Chinese Wills Validation Ordinance 1856 and the Wills Act 186 I (U.K.). The committee proposed that Chinese, whatever their domicile, might dispose of their property by will and that oral wills should not be permitted. ${ }^{101}$ Reference may also be made to $F u$ Chuen Sang and anor. v. Cheung Ching Tak and ors. ${ }^{102}$ where it was held that a "wish" for a wife to adopt a son did not create a precatory trust. It should be noted that this case was decided solely on English authorities.

There are only two reported cases from Sarawak ${ }^{103}$ in which it was held that the validity and construction of a Chinese will are to be governed by English law. If the will attempts to dispose of property according to Chinese custom then it will be given effect to if the custom is regulated or recognized by a Sarawak ordinance or by rules made under any Sarawak ordinance.

In both the Straits Settlements and the Federated Malay States the validity of wills made by Chinese was tested by reference to English principles of construction (this is apart from questions of charitable uses). In Lee Eng Nam v. H.T. Jones $^{\mathbf{1 0 4}}$ it was held that a Chinese widow could make a will because there was nothing either in the common law or in the Perak Order in Council to show lack of testimentary capacity.

In Re Lee Kim Chye decd. ${ }^{105}$ the court held that when a Chinese marries a secondary wife after making a will such marriage revokes the will.

Trusts for charitable uses-perpetuities: Trusts for charitable uses fall into two classes: a trust for the purchase of land to be used as a burial place for a person or family; and trusts for the performance of ancestor worship. ${ }^{100}$ In the only two cases reported from Hong Kong the court held that bequests for "worshipping

${ }^{99}$ Khoo Hooi Leong v. Khoo Choong Yok [1930] S.S.L.R. 127. In re Khoo Tek's Settlements [1929] S.S.L.R. 50.

100 In the estate of Choo Eng Choon decd. (IgrI) I2 S.S.L.R. I 20 at 224.

${ }_{101}$ Chinese Law and Custom in Hong Kong-report pp. 63-64.

102 [1961] H.K.L.R. 219.

${ }^{103}$ Chan Bee Neo and ors. v. Ee Siok Choo [1947] S.C.R. I. Re Tay Lim Tiang decd. [1955] S.C.R. I7.

104 (1923) 3 F.M.S.L.R. 42.

105 [1936] M.L.J. 49.

108 Variously referred to in the reports as sin chew, chin shong. 
expenses" and "Ancestor's Sacrificial Fund" were invalid as offending the rule against perpetuities though they were not superstitious uses. ${ }^{107}$

After some hesitation the courts in Malaya and Singapore have held that a trust for the purchase of burial ground is a valid charitable trust. ${ }^{108}$ This is so even though the use of the property was for members of a certain seh only. ${ }^{109}$ The justification for this appears to be that a seh is a public charity since it is set up to provide burial and worship facilities for its members. ${ }^{110}$ Similarly, trusts made for the establishment and upkeep of temples and worshipping places have been considered valid. ${ }^{111}$

Trusts for the purposes of ancestor worship have two aspects. First, the courts have had to consider whether or not they are valid or are superstitious uses. Once again, after some hesitation, they have been held to be valid trusts. In $\operatorname{Re} K$ Khoo Cheng Teow decd. ${ }^{112}$ the court held that such a gift is not superstitious but is more in the nature of a gift, for example, to say Masses and may be approved on the same grounds. In an earlier case, Choa Cheow Neo v. Spottiswoode ${ }^{113}$ a gift for the purpose of sin-chew was held invalid on the ground that it was not charitable, being of benefit to the testator only. However, in Lim Chooi Chuan v. Lim Chew Chee ${ }^{114}$ a trust providing for the carrying out of sin-chew by the members of one seh was held charitable in that it benefitted one part of the public.

The second aspect is the question of perpetuities. A trust for sin-chew is valid only if drawn so as not to infringe this rule. ${ }^{115}$ In addition it must be certain. Thus, for example, a sin-chew trust for the benefit of a "Chinese family" has been held bad for uncertainty. ${ }^{116}$ Similarly, a direction to spend income on "yearly ceremonies according to Chinese custom" was held uncertain. ${ }^{117}$ Where a trust for sin-chew is impressed on real property outside the jurisdiction the court will judge the validity of the direction according to the law of the place where the property is situated. Thus, where the real property was in China and the trust valid at Chinese law, the courts recognized it. ${ }^{118}$

As with all other facets of Chinese custom so far considered any custom must be proved or provable to the satisfaction of the court. ${ }^{118}$

Administration and Succession. ${ }^{120}$ Apart from adopted persons the main problem ${ }^{107}$ In Re Chan Quan Ee (1920) 15 H.K.L.R. 74; Lan Leung Shi v. Lau Po Tsun (1911) 6 H.K.L.R. I 49 .

${ }^{108}$ Lee Poh Lian Neo and ors. v. The Chinese Bankers Trust Co. Ltd. [194I-42] S.S.L.R. 28.

109 Cheang Tew Muey and ors. v. Cheang Cheow Lean Neo \& ors. [1930] S.S.L.R. 58.

110 Yeoh Him \& ors. v. Yeah Cheng Kong and ors. (1889) $4 \mathrm{Ky}$. 500: see contra. Re Yap Kuan Seng. decd. (1924) 4 F.M.S.L.R. 3 I3.

111 Tan Chin Ngoh v. Tan Chin Teat and ors. [1946] S.L.R. 14; Re Low Kim Pong's Settlement Trusts [1938] S.S.L.R. I 44 .

112 [1932] S.S.L.R. 226: see also Ong Geok Neo v. Chee Hoon Bong and ors. (1893) I S.S.L.R. 53;

Phan Kin Thin v. Phan Kuow Yung [1940] M.L.J. 35.

113 (I 869) I Ky. 216.

114 [ $1948-49]$ M.L.J. Supp. 66.

115 Re Tan Kim Seng decd. (I9II) 12 S.S.L.R. I. Re the trusts of Wan Eng Kiat [193I] S.S.L.R. 57.

${ }^{116}$ Re the trusts of Wan Eng Kiat [193I] S.S.L.R. 57.

117 Re Chen Ah Sang deed. [1949] M.L.J. I4.

${ }^{118} \mathrm{Ng}$ Eng Kiat v. Goh Lai Mui \& ors. [1940] S.S.L.R. 78.

${ }^{119}$ Choy Mien Hew v. Choy Weng Tung and anor. [1932] S.S.L.R. 126. See also Li Chik Hung v.

Li Pui Choi (IgII) 6 H.K.L.R. I 2 where the law as to "ancestral property" had to be proved on the ground that there is no such form of property in English law.

120 Not including the rights of adopted persons - see above "adoption". 
current in this topic has arisen in respect of the rights of secondary wives to administer and succeed, especially with respect to intestate property.

The Hong Kong courts have long settled the law in the colony that in succession to property the operative law is T'sing law or local Chinese custom. However, the law as to the mechanics of administration is English law. Thus, for example, the grants of letters of administration is governed by English law but the manner of distribution is government by $T^{*}$ sing law. ${ }^{121}$ The substance of Chinese law must of course be proved to the satisfaction of the court. ${ }^{122}$ On administration, the Hong Kong courts have held that a concubine ${ }^{123}$ and a widow may administer. The widow may, however, administer only so long as she remains a member of her late husband's family. The fact that she re-marries does not affect this so long as (the court held) she introduces her second husband into the house of her late husband. ${ }^{124}$

On the right of a widow to succeed, the court has held that she has no absolute right but, subject to her right of maintenance, on behalf of the male succession. ${ }^{125}$ If the male line becomes extinct the property will descend to the surviving female relatives of the last deceased male member: this right is not confined to daughters or spinsters. ${ }^{126}$

The courts in former North Borneo have made no pronouncements specifically on administration and succession apart from the general principle that any proved or accepted Chinese custom will prevail over English law. ${ }^{127}$ Presumably this is subject to the overriding authority of Sarawak statutes and rules. ${ }^{128}$

The courts in Malaya and Singapore have consistently held that the distribution of a Chinese intestate estate is governed exclusively by the Statute of Distributions. In Lee Joo Neo v. Lee Eng Swee ${ }^{128}$ the court gave two reasons for this. First, that immovable property is governed by the lex loci rei sitae and Chinese law cannot be incorporated within the Statute of Distributions. Second, that movable property is governed by the law of the domicile which does not allow Chinese law to be incorporated in the Statute. This has been recently approved in Re Chia Eng Say $\operatorname{dec} d^{130}$ where the Court said it would not consider any Chinese customs with respect to the Statute. ${ }^{131}$

121 Wong Pan Ying v. Wong Ting Hong [1963] H.K.L.R. 37: see also Chan Yeung v. Chan Shew Shi (1925) 20 H.K.L.R. 35; Ho Cheng Shi v. Ho Sau Lam (1920) I5 H.K.L.R. 35; Chan Shun Cho v. Chak Hok Ping (1925) 20 H.K.L.R. I; Ho Tsz Tsun v. Ho Au Shi and ors. (19I5) ro H.K.L.R. 69.

122 Li Chik Hung v. Li Pui Choi (1911) 6 H.K.L.R. I2.

${ }^{123}$ Ho Sau Lam v. Ho Cheng Shi (1916) II H.K.L.R. 92.

${ }^{124}$ In Re the Estate of Ngai I. (1927) 22 H.K.L.R. 105.

125 Tang Choy Hong v. Tang Shing Mo \& ors. (1949) 33 H.K.L.R. 58.

126 In Re the estate of Ngai I. (1927) 22 H.K.L.R. I05.

${ }_{127}$ Re Tay Lim Tiang decd. [1955] S.C.R. I7.

128 Kho Leng Guan v. Kho Eng Guan [1928-4I] S.C.R. 60.

120 (I 887$) 4 \mathrm{Ky}, 325$.

130 [195I] M.L.J. I30.

131 Attention is here drawn to the case of Yap Tham Thai (alias) v. Low Hup Neo (1922) I F.M.S.L.R. 383 ; (1925) 6 F.M.S.L.R. 13. Here it was held that succession to the estate of an intestate Chinese domiciled in Selangor should be distributed according to the broad principles of Chinese family law as set out in the Perak Order in Council (No. 23 of 1893) as modified by certain rules of local custom. In coming to this conclusion the court based itself upon the following grounds: (a) There is no Chinese personal law similar to that of Muslims or Hindus; (b) There is a common law of Selangor applicable in this case; (c) The intestate must be regarded as of "British nationality."

This case was, however, a decision from the Federated Malay States into which English law was never introduced in its entirety. The judge, therefore, seems to. have assumed that the Statute did not 
As far as secondary wives are concerned the result of applying the Statute has been that the courts will order joint administration of intestate property. ${ }^{132}$ In the Straits Settlements, the court has ordered equal shares of intestate property to be given. The reason for this is that since English law provides no rule for determining the proportions, the court cannot order any proportion other than an equal share. Though in China the second wife may have no right to share, this was held immaterial in the Straits Settlements because a first wife would not find it any easier to establish her right to letters of administration than would the second. ${ }^{133}$

The courts have also had to deal with the situation of succession to the estate of deceased secondary wife. The court presumed intestacy from the rarity of wills among Chinese women of her class ${ }^{134}$ and then went on to hold that, in the absence of proof to the contrary, such a woman could not have a successor. Her estate was therefore declared bona vacantia. ${ }^{135}$ In effect this decision overruled the decision in Yap Kan Keow and anor. v. Low Hup Neo and anor. ${ }^{138}$ which itself arose out of and is part of the decision in Yap Tham Thai (alias) v. Low Hup Neo. ${ }^{137}$ The question remains unsettled except that now the new Distribution Ordinance, No. I of 1958 , may help to solve the problem.

This completes our summary of judicial decisions in the three territories. Each of these territories has had its own method of dealing with substantive provisions of Chinese law which are largely dependent upon their differing legal bases. The bulk of Chinese law has been dealt with, however, in a remarkably similar fashion in each of the territories.

At the present time each territory in which Chinese law is still a valid system of personal law (i.e. Malaya, Sabah, Sarawak, Brunei, and Hong Kong) is facing new problems which are themselves partial results of the past treatment of Chinese law. The only exceptions to this generalization are the states of Sabah, Sarawak, and Brunei where because of the commonsense approach of the courts in refusing to lay down principles at substantive Chinese law, ${ }^{138}$ the continued validity and flexibility of this law remains unimpaired.

\section{Current Problems}

Hong Kong. The report of the committee on Chinese law and custom in Hong Kong drew attention to various problems facing the judiciary in 1953. The most important of these appears to be the problem of domicile as determining the jurisdiction of Hong Kong courts. This is especially serious in view of the judg-

\footnotetext{
apply in the Federated Malay States and that he was subject to local legislation viz. the Perak Order in Council. Distribution of an intestate estate is now governed by Ordinance No. 1/1958 replacing cap. 71/1930-revised laws of the Federated Malay States, 1935.

132 In the goods of Ing Ah Mit (1888) 4 Ky. 380.

${ }^{188}$ In the goods of Lao Leong $A n$ (1893) I S.S.L.R. I.

134 Lee Siang Neo and ors. v. Low Hin Tuan and ors. (1925) 5 F.M.S.L.R. 154.

${ }^{135}$ Official Administrator F.M.S. for Chua Swee Sim Neo decd. v. State of Selangor and ors. [1939]

M.L.J. 175.

136 (1925) 6 F.M.S.L.R. I3.

137 See note I3I above.

188 Preferring instead to rely upon expert evidence on a case by case basis and refusing to be bound by too rigid a scheme of precedent.
} 
ment in Lau Leung Shi v. Lau Po Tsun ${ }^{139}$ where it was held that as long as a Chinese continued to worship at his ancestral temples, he could not get a domicile of choice in the colony. The committee recommended, ${ }^{140}$ quite rightly, that this artificial test on change of status should not continue. The suggested solution was to raise a presumption in favor of change of domicile on the following grounds:

(a) If a Chinese has lived in Hong Kong for seven years after attaining the age of twenty-one; and before the date at which he claims a new domicile.

(b) If he married in Hong Kong and lived there for five years after the date of marriage and before the date at which he claims a new domicile.

(c) If he has acquired British nationality.

(d) If he was born in Hong Kong and has resided there continuously.

These have now been given statutory effect in the Divorce (Amendment) Ordinance $\left(44 / \mathrm{r} 5^{6}\right)$. The committee also recommended the passing of a bill entitled the Chinese Law and Custom (Miscellaneous Provisions) Ordinance containing the same provisions and determining also what matters should be settled by common law on questions of domicile, capacity, and change of status. ${ }^{141}$ There are as yet no reported cases on this topic and the effects of this legislation and of the committee's recommendations remain to be seen.

Malaysia (not including Sabah, Sarawak and Brunei). Because of the judicial history of the Federated and Unfederated Malay States an entirely different set of problems arises in Malaya. These revolve around the Chinese Christian who has entered into a series of polygamous marriages. We may illustrate this with two examples.

The first of these is Re Loh Toh Met: Kong Lai Fong v. Loh Heng Peng. ${ }^{142}$ In this case the Court had to decide what law governed the validity of various marriages entered into by a Christian Chinese now deceased. The deceased died possessed of three wives and eleven children (of whom four were ostensibly adopted). He had been brought up a Roman Catholic though he was sporadic in his religious observances. On this evidence the trial judge held that the deceased was a person professing the Christian religion under the Christian Marriage Ordinance. ${ }^{143}$ From this the judge concluded that the deceased had been obliged to marry under the Ordinance and in that all his marriages were entered into by Chinese ceremony, none of them was valid.

On appeal, however, the Court held that the deceased was not in fact a Christian and that being a man of "Chinese race" the provisions of his customary law should apply to him. The introduction of "Christian" into this decision is unfortunate and, because of the provisions of the Ordinance, unnecessary. ${ }^{144}$ It is the law that a Chinese even if professing the Christian religion can enter into a polygamous marriage by Chinese customary rites. Christianity by itself is not qualification for a state of monogamy. Similarly, the introduction of "race" is also unfortunate. I

\footnotetext{
139 (I9II) 6 H.K.L.R. 149.

240 Report of the Committee op cit. pp. 66-67 and Appendices 18 and 19.

141 lbid. pp. 306-09 (Appendix 2I).

142 [196I] M.L.J. 234.

243 Cap. 82 revised laws of the Straits Settlements 1936.

144 See a note on this case by David C. Buxbaum in (1963) 5 Malaya Law Review 383-87.
} 
should guess that anthropologists would not generally classify the Chinese as a race. If the Court makes this a criteria in any decision then it runs the risk in the future of having to determine whether a person of mixed ancestry is a member of the "Chinese race." The Court instead must concentrate upon establishing the personal law of any litigant.

One further point arises from this decision. The four adopted children of the deceased failed in their claim for a share in the estate. This was because the Distribution Ordinance 1958 , of Malaya, restricts the status of adoption to those persons formally adopted under the Adoption Ordinance of 1952. The Courts have consistently refused to recognize adoptions at customary law among the Chinese in Malaya and this has caused not inconsiderable hardship. The Chinese themselves feel a sense of injustice at this state of affairs. ${ }^{145}$

The second example of this situation is Re Ding Do Ca. ${ }^{146}$ The issue in this case was whether or not a Chinese who had married under the Christian Marriage Enactment ${ }^{147}$ could subsequently contract a marriage under Chinese custom while the first marriage was still subsisting. The Court held that he could as there was nothing in the Enactment which corresponded to s. 4 of the Civil Marriage Ordinance ${ }^{148}$ which would prohibit such a union (Thomson L. P.). In effect the judge refused to equate Christianity with monogamy, but instead equated "Chinese" with polygamy.

It is submitted that both equations are wrong and subject to the difficulties of proof outlined in respect of Loh Toh Met. The solution appears to force a return to a factual ascertainment of personal law leaving aside as irrelevant race or Christianity. In the case of a Chinese Muslim the position is different. He is subject to Islamic law: the faith includes a legal system. A Chinese Christian, however, is not subject to "Christian Law": there is no such thing. He is governed by his personal law insofar as this remains effective under statute.

To summarize: Chinese law continues to be a viable system of personal law in (east and west) Malaysia and in Hong Kong, though no longer in Singapore. Judicial pronouncements have been comparatively more common in Malaysia than in Hong Kong and this is probably a reflection of the wider scope and effect of statute in Hong Kong. The cases from this area also show a proportionately greater interest in matters of business transactions and organizations conducted according to customary rules.

The future of Chinese custom in these areas is assured though limited mainly to matters of family law. Even here, however, there is increasing statutory interference which seems directed at trying to bring the substantive provisions of custom in line with the rest of the law. Singapore has gone the furtherest in this endeavor and has completely banned the recognition of Chinese family law, most notably in its refusal to countenance polygamous marriages. How effective this has been on the lower stratum of Singapore society is unknown but it would not be surprising if many of these unions were still being entered into. But even in

\footnotetext{
145 See Maurice Freedman, "Colonial Law and Chinese Society," Journal of the Royal Anthropological Institute (1950) $1 \times x \times 97$ at 112.

148 [ 1966$]$ M.L.J. 220.

147 Christian Marriage Ordinance 1956 (Malaya). This is a substantial re-enactment of cap. Io9 revised laws of the Federated Malay States, I935.

148 Ordinance No. 44 of 1952.
} 
Singapore some vestiges of Chinese custom come to the surface now and again. Thus, the traditional "peacemaker" is still active in minor matrimonial affairs and in the Chinese business community (report in the Straits Times, 25 May I966). This is a subject which needs detailed exploration.

In the lower courts in Malaysia the magistrates have recognized the cutting off of a white cockeral's head as a form of oath (report in the Straits Times, 25 February I968, I7 March 1968). These examples, isolated though they are, emphasize that much research must be done at grassroots level.

\section{KEY TO ABBREVIATIONS}

A.C.

Cl. \& F.

F.M.S.L.R.

H.K.L.R.

Ky.

Leicester

L.R.P. \& D.

M.L.J.

M.L.J. Supp.

S.C.R.

S.L.R.

S.S.L.R.

W.O.C.
Appeal Cases. United Kingdom, I 866-current.

Clark \& Finnelly. House of Lords Cases. 12 vols. $1831-1846$.

Federated Malay States Law Reports. By J. R. Innes and McLean. Cases decided from 1922-31, 7 vols. New Series by H. C. Willan 1932-47. No report $1942-45$.

Hong Kong Law Reports. Hong Kong, 1906-current.

Kyshe's Law Reports. By J. W. N. Kyshe. 4 vols. Vol. I-Civil cases

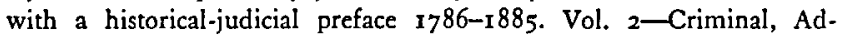
miralty, Bankruptcy, Ecclesiastical and Habeas Corpus cases. Vol. 3Magistrates Appeals. Vol. 4-Cases 1885, 1890; Rules and Orders of Court 1885-1890.

Leicester's Reports: by S. Leicester (also known as Straits Law Reports-Leicester). Cases decided in the Supreme Court of the Straits Settlements, I vol. 1877 .

Law Reports. Probate and Divorce Cases. 3 vols. I865-1875.

Malayan Law Journal. Cases decided in Malaysia, Singapore and (from 1963-64) Sarawak, North Borneo and Brunei. By B. A. Mallal. r932current.

Malayan Law Journal Supplement. By B. A. Mallal. Contains cases unreported and some cases noted in [1949] M.L.J.: published in 1957. [1949] Supplement published in $195 \mathrm{I}$.

Supreme Court Reports. Cases decided in Sarawak, 1928-4I, 1946-5I. From 1952 includes reports from North Borneo and Brunei. Ceased publication with the volume for $1960-63$.

Singapore Law Reports. Cases decided from $1946-49$, 1953-56. 8 vols.

Straits Settlements Law Reports. Old Series, 1893-1907. New Series, 1926-1941/42. Published under the direction of the Singapore Bar Committee.

Woods Oriental Câses. A selection of the cases decided in the Supreme Court of the Straits Settlements. By R. C. Woods, Jr. Penang: 1869 (reprinted Sweet \& Maxwell, London, I9II). 